\title{
Learners' Characteristics And Academic Performance: A Study Of Kwame Nkrumah University Of Science And Technology Primary School, Ghana
}

\begin{abstract}
The learner has a significant role to play in improving his/her academic performance. This study investigated learners' characteristics contributing to low academic performance in primary school. The study focused on the Kwame Nkrumah University of Science and Technology Primary School in Kumasi, Ghana. Using a qualitative approach, one hundred and twenty (120) learners, sixty (60) parents and thirty-five (35) teachers were purposively sampled using questionnaires, interviews and informal discussions respectively. Responses of learners revealed that some of them felt rejected by peers, did not understand lessons taught, while some were inattentive and attention seekers who tend to disrupt the concentration of studious learners. The findings showed that lack of parental motivation and assistance negatively impact academic work of learners. The study recommends that a guidance and counselling unit be set up in schools to assist learners develop attitudes and habits for academic achievements.
\end{abstract}

Keywords: Learners' characteristics, academic performance, guidance and counselling, socio-economic status, motivation.

\section{OLIVIA AKROFI ${ }^{1}$}

${ }^{1}$ OLIVIA AKROFI is a Chief Teacher at Kwame Nkrumah University of Science and Technology (KNUST) Primary School. She holds a Master of Philosophy (Educational Innovation and Leadership Science) from KNUST, Kumasi-Ghana and a Master of Education (Guidance and Counseling) University of Cape Coast,

Cape Coast- Ghana.

Email: ooakrofi@gmail.com

Manuscript

Received 26th March 2020,

Accepted 18th May 2020,

Published online 25th May 2020.

\section{INTRODUCTION}

School is part of the process of secondary socialization of the child where formal education and other charactermoulding behaviours are taught. As such, the core aim of every school is to produce learners with good academic outcomes. Children have the extra challenge of learning new behavioural patterns that fit into the relatively unfamiliar school environment with teachers as new authority figures who enforce new rules and regulations.

It is believed that academic performance of a learner is partly attributed to his or her ability to study effectively through self-discipline and hard work. Other learner-related factors such as self-concept, school attendance, attitude and habit, intelligence quotient, time management and motivation among others are associated with academic performance. Some are of the view that school is quite stressful and examination time can be particularly disturbing. ${ }^{2}$ The researcher agrees that teachers play the role of "psychologists" for learners who have domestic and personal challenges. ${ }^{3}$

In recent years, there have been records of declining academic performance of learners in primary schools. Hence, the study sought to investigate learner characteristics that contribute to low academic performance using the Kwame Nkrumah University of Science and Technology (KNUST) Primary School - Ghana. Learners are from different backgrounds; hence it is suitable for identifying learner-related factors affecting academic performance and measures that could be used for academic improvement of learners.

\footnotetext{
2 Emma Dawson-Brew, Vera Ankomah-Sey, and Eric Nyarko-Sampson. "The relative effect of Field Dependent and Field Independent learning styles on the academic performance of undergraduate students of the University of Cape Coast, Ghana." IFE PsychologIA: An International Journal 18, no. 2 (2010): 48-64.

3 Daniel Andreas Louw. Human development. Pearson South Africa, 1998.
} 


\section{LEARNERS' CHARACTERISTICS AND ACADEMIC PERFORMANCE}

Tella states that the learner has a key role to play in improving his $\backslash$ her academic standard. ${ }^{4}$ These researchers purport that learners' characteristics that influence academic achievement in primary school include school attendance, learners' attitudes and habits, time use, motivation and self-esteem among others. ${ }^{5}$ Therefore, parents and teachers have a fundamental role to play in shaping children to develop and adopt strategies to enhance their academic success.

\section{School attendance}

A learner's regular attendance at school greatly contributes to his/her academic performance. Poor school attendance no matter the reason reduces the quantity of instruction a learner is expected to receive from the classroom as well as his/ her understanding of major concepts in the syllabus. ${ }^{6}$ Attendance is influenced by the learners' perception about school, which is a significant determinant of academic achievement. Therefore, it is incumbent upon teachers and parents to encourage learners to develop interest in school.

Parents should endeavour to provide children with adequate food nutrients to enable them stay healthy and strong for school so that ill health does not keep them from the classroom. Authoritative parenting also leads to the instillation of socially acceptable behaviour in children. ${ }^{7}$ Such children are punctual and obedient to school rules / regulations and thus perform better in school.

Stewart reported that school attachment and commitment to a large extent contribute to school achievement. ${ }^{8}$ Personal experience of the researcher has revealed that girls take interest in tidying up and running errands in the classroom. Again, they enjoy practical tasks such as cooking and needlework and perform better in these areas.

\section{Attitudes and Habits}

Dawson-Brew et al explain that academic achievement is dependent on an individual's ability to study effectively. ${ }^{9}$ They purport that girls as well as younger learners are usually more involved in school activities than boys and older ones. ${ }^{10}$ When learners make conscious effort to study, they are able to develop the habit of studying effectively to improve their academic performance. It is rather unfortunate that many learners lack the zeal to study for academic success. It is important to state that some learners have peculiar problems in paying attention in class; examples are children with Attention Deficiency Hyperactive Disorder (ADHD) and Attention Deficit Disorder (ADD) ${ }^{11}$. These disorders are characterized by socially disruptive behaviour; either attentional problems or hyperactivity. Literature also proves that children with ADHD are likely to show significant academic underachievement ${ }^{12}$. Teachers should endeavor to guide learners and engage them in performing tasks in the classroom whereas parents monitor their homework.

The researcher agrees with others that learners encounter several challenges in developing positive study attitudes and habits in school. ${ }^{13}$ Peer pressure and indiscipline are typical challenges learners face. It behoves on parents and teachers to instill discipline in learners to help them avoid bad company.

A constructive study habit is when learners focus on their school work, search for appropriate information, set time for homework, are punctual, ask teachers questions and study in groups when they do not understand concepts

$4 \quad$ Adedeji Tella, "The impact of motivation on student's academic achievement and learning outcomes in mathematics among secondary school students in Nigeria." Eurasia Journal of Mathematics, Science \& Technology Education 3, no. 2 (2007): 149-156.

5 Dawson-Brew, Emma, Vera Ankomah-Sey, and Eric Nyarko-Sampson. "The relative effect of Field Dependent and Field Independent learning styles on the academic performance of undergraduate students of the University of Cape Coast, Ghana." IFE PsychologIA: An International Journal 18, no. 2 (2010): 48-64.Gina Chowa, "How Do Student and School Characteristics Influence Youth Academic Performance in Ghana? A Hierarchical Linear Modeling of Baseline Data from the YouthSave Ghana Experiment." (2013).

6 Olivia Akrofi, Parental involvement of School Guidance and Counselling of the Adolescent.Unpublished. Cape Coast, Cape Coast, Ghana. 2009.

7 S. Aremu, and B. Oluwole. "The development and validation and academic performance. 5 Factor Inventory: An unpublished manuscript department of guidance and counselling." University of Ibadan, Ibadan (2000).

8 Endya B. Stewart "School structural characteristics, student effort, peer associations, and parental involvement: The influence of school-and individual-level factors on academic achievement." Education and urban society 40, no. 2 (2008): 179-204.

9 Emma Dawson-Brew, Vera Ankomah-Sey, and Eric Nyarko-Sampson. "The relative effect of Field Dependent and Field Independent learning styles on the academic performance of undergraduate students of the University of Cape Coast, Ghana." IFE PsychologIA: An International Journal 18, no. 2 (2010): 48-64.

10 Robert Crosnoe, Monica Kirkpatrick Johnson, and Glen H. Elder Jr. "School size and the interpersonal side of education: An examination of race/ethnicity and organizational context.” Social Science Quarterly 85, no. 5 (2004): 1259-1274.

11 David Daley, \& James Birchwood. "ADHD and academic performance: why does ADHD impact on academic performance and what can be done to support ADHD children in the classroom?" Child: care, health and development 36, no. 4 (2010): 455-464.

12 Ibid

13 Luke Moloko Mphale, and Mavis B. Mhlauli. “An investigation on students' academic performance for junior secondary schools in Botswana." European Journal of Educational Research 3, no. 3 (2014): 111-127. 
taught in the classroom. ${ }^{14}$ Adane stresses that teachers ought to play a dual role of teacher and psychologist as they impact knowledge and skills to learners. Proper guidance by parents and teachers enable learners to perform well in examinations. ${ }^{15}$ This supports the assertion of Hussain that, guidance from teachers and parents sharpens the intelligence of learners. ${ }^{16}$ There should be a guidance and counselling session in schools to guide and assist learners develop positive attitudes to self, peers and studies.

\section{Intelligence quotient}

Intelligence includes the volume of logic, thoughtfulness, self-awareness, learning, emotional knowledge, reasoning, planning, creativity and problem solving. ${ }^{17}$ Intelligence quotient (IQ) is a number that characterizes an individual's intellectual ability as equated to the statistical norm or average for one's age, taken as 100 . The total score is derived from numerous standardized tests designed purposely for assessing human intelligence. It measures cognitive capacity relative to peers. ${ }^{18}$

Teachers may notice low IQ from delayed arithmetic, writing, reading, speech and understanding. A child with intellectual deficiencies tends to grieve in school because he or she is measured and compared with others. A learner may experience humiliating insults from peers. A combination of other factors such as socio-economic status, learning resources and time management influences one's academic performance and achievement. ${ }^{19}$

\section{Time management}

Mutsotso and Abenga believe that many learners do not know how to manage their time effectively. ${ }^{20}$ Today's learners in the basic school are more interested in playing computer games, fidgeting with electronic gadgets, watching television and engaging in other activities at the detriment of their studies. Erling argues that the amount of time a learner spends learning is one of the most valuable indicators for academic achievement. ${ }^{21}$ Mendezabal agrees with this assertion that learners who fail their examinations do so not because they are incapable but because of poor study habits and strategies. Carbonaro is in support of studies that show that learners' effort in learning is connected to their value for education. ${ }^{22}$ Effort is measured in different ways ranging from time spent on homework to a learner's attentiveness in the classroom. ${ }^{23}$ Learners must be motivated to learn and devote sufficient time for their books. There is an old adage that says 'practice makes a person perfect'. Thus, if learners spend more time learning, their academic performance is likely to improve.

\section{Motivation}

Maslow's hierarchy of human needs was one of the first theoretical frameworks of understanding motivation. Girmus explains motivation by dividing it into two components; intrinsic and extrinsic. Intrinsic motivation is defined as an unnoticeable inner condition that provides the basis for a human goal-directed behaviour whereas extrinsic is the drive to achieve external rewards. ${ }^{24}$ Both components can effectively play a motivational role in any given academic setting. Mphale and Mhlauli assert that lack of motivation adversely affects academic achievement. ${ }^{25}$ They further indicate that learners' motivation can be influenced by the way a teacher introduces and presents a new task. However, if the task does not make the learner competent it will not activate motivation.

A motivated learner is likely to perform a task well to increase output. When learners are motivated to learn

\footnotetext{
${ }_{14}$ Emma Dawson-Brew, Vera Ankomah-Sey, and Eric Nyarko-Sampson. "The relative effect of Field Dependent and Field Independent learning styles on the academic performance of undergraduate students of the University of Cape Coast, Ghana." IFE PsychologIA: An International Journal 18, no. 2 (2010): 48-64.

15 Linda Ofosua Adane. "Factors affecting low academic achievement of pupils in Kemp Methodist Junior High School in Aburi, Eastern region." PhD diss., University of Ghana, 2013.

16 Ch, Abid Hussain. "Effect of guidance services on study attitudes, study habits and academic achievement of secondary school students." Bulletin of Education \& Research 28, no. 1 (2006): 35-45.

17 Tias Anggi Pratama, Syamsuri Istamar and Adi Atmoko. "The contribution of intelligent quotient on biology academic achievement of senior high school students in Medan, Indonesia.

18 Daniel Andreas Louw, Human development. Pearson South Africa, 1998.

19 Luke Moloko Mphale, and Mavis B. Mhlauli. "An investigation on students' academic performance for junior secondary schools in Botswana." European Journal of Educational Research 3, no. 3 (2014): 111-127.

20 S. N. Mutsotso and E. S. B. Abenga. "Study methods for improving quality learning and performance in higher education." (2010).

21 S. Erling. "Allocating time within the school year calendar: A review of the literature." (2007). Marie Jean N Mendezabal. "Study habits and attitudes: The road to academic success." Open Science Repository Education open-access (2013): e70081928.

22 William Carbonaro. "Tracking, students' effort, and academic achievement." Sociology of Education 78, no. 1 (2005): $27-49$.

23 Jennifer Barry. "The effect of socio-economic status on academic achievement [PhD dissertation]." Wichita, Kansas: Wichita State University (2005).

24 Ronald L. Girmus, "How to Motivate Your Students." Online Submission (2012).

25 Luke Moloko Mphale, and Mavis B. Mhlauli. "An investigation on students' academic performance for junior secondary schools in Botswana.” European Journal of Educational Research 3, no. 3 (2014): 111-127.
} 
they tend to put in more effort to improve their standard. Ige and Ogunleye opine that it is imperative for teachers and parents to motivate learners in order to ignite and sustain their interest to learn more and to boost their self-concept. ${ }^{26}$ Interestingly, psychologists have developed a plan including rewards, praise, positive self-concept/esteem as well as appropriate feedback to aid teachers motivate learners in the classroom. ${ }^{27}$

\section{Self-concept/esteem}

Self-concept is an important component of an individual's personality. ${ }^{28}$ It refers to how a person views and evaluates himself/herself. Self-concept is one's knowledge of oneself in relation to what he or she can achieve academically. Self-esteem is usually based on the self-evaluation of an individual's characteristics or qualities. It is the extent to which an individual feels, receives love, acceptance, support and encouragement from others. ${ }^{29}$ Ajayi et al affirms that the development of a child's self-concept is partly dependent on the way and manner he or she is nurtured by parents at home. ${ }^{30}$

The degree of self-acceptance plays a vital role in children's personality and influences all facets of their development. Learners with positive self-concept usually are more independent, creative and successful academically than those who develop negative self-concept. Low self-esteem results in anxiety, poor academic performance and inadequate social adjustment. ${ }^{31}$ Self-concept, self-worth, attitude and motivation are directly related to academic success and make learners differ in their commitment in school activities. Self-concept is developed from an individual's diverse interactions with society. ${ }^{32}$ Two important sources of social support that contribute to a learner's self- esteem are his or her relationship with peers and parents. ${ }^{33}$ Hence, there is the need for teachers and parents to create opportunities where learners can interact with their peers. Activities such as singing and dancing, sports and other group programmes to a large extent boost one's self-esteem. Diaz, as well as Adane, are of the view that a learner's self-esteem, his/her rejection and acceptance by peers, are of great significance to his/her academic performance and achievements.$^{34}$

\section{METHODOLOGY}

The study employed the mixed method. It made use of the qualitative and quantitative approaches. One hundred (120) learners, sixty (60) parents and thirty-five (35) teachers were purposively sampled. Questionnaires were administered to learners, teachers and parents to collect primary data. The researcher also engaged informal discussions with teachers to gather qualitative data from the interviewees. The Statistical Package for the Social Sciences (SPSS) software (version 25) was used in analyzing the quantitative data.To make the analysis easier positive responses (strongly agree and agree) were summed up and equated to "agree" whereas the negatives (strongly disagree and disagree) were also summed up and equated to disagree.

\footnotetext{
26 Michael, Ige Olusegun, and Ogunleye Akinyemi Wumi. "Causes and remedies to low academic performance of students in public secondary schools: A study of Ijero local government area of Ekiti State." (2016).

27 Suzanne Hidi. "Revisiting the role of rewards in motivation and learning: Implications of neuroscientific research." Educational Psychology Review 28, no. 1 (2016): 61-93.

28 Carol S. Dweck, Gregory M. Walton, and Geoffrey L. Cohen. "Academic Tenacity: Mindsets and Skills that Promote Long-Term Learning." Bill \& Melinda Gates Foundation (2014).

29 Johan Ferla, Martin Valcke, and Yonghong Cai. "Academic self-efficacy and academic self-concept: Reconsidering structural relationships.” Learning and individual differences 19, no. 4 (2009): 499-505.

30 O. K Ajayi, A. O. Lawani, and M. O. Salomi. "The influences of self-concept and academic motivation on students' attitude to mathematics in selected secondary schools in Ogun State, Nigeria." European Journal of Scientific Research 67, no. 3 (2012): 444-455.

31 Daniel Andreas Louw. Human development. Pearson South Africa, 1998.

32 Gina Chowa, "How Do Student and School Characteristics Influence Youth Academic Performance in Ghana? A Hierarchical Linear Modeling of Baseline Data from the Youth Save Ghana Experiment.” (2013).

33 Linda Ofosua Adane. "Factors affecting low academic achievement of pupils in Kemp Methodist Junior High School in Aburi, Eastern region." PhD diss., University of Ghana, 2013.

34 Antonia Lozano Diaz. "Personal, family, and academic factors affecting low achievement in secondary school." Electronic Journal of Research in Educational Psychology and Psychopedagogy 1, no. 1 (2003): 43-66.
} 


\section{RESULTS AND DISCUSSION}

Table 1 shows the demographic characteristics of learners.

Table 1 Demographic characteristics of learners

\begin{tabular}{llll}
\hline Variable & Category & Frequencies & Percent (\%) \\
\hline Gender & Male & 68 & 56.7 \\
& Female & 52 & 43.3 \\
Age & 8 years and below & 1 & \\
& $9-11$ & 84 & 0.8 \\
& $12-15$ & 35 & 70.0 \\
Number of siblings & & & 29.2 \\
& None & 6 & 5.0 \\
& $1-3$ & 71 & 59.1 \\
& $4-6$ & 39 & 32.5 \\
& $7-10$ & 4 & 3.3 \\
Lives with biological parents & Yes & 114 & 95 \\
& No & 6 & 5.0 \\
Guardian's employment status & Unemployed & 22 & 18.3 \\
& Self-employed & 68 & 56.7 \\
& Public servant & 30 & 25.0 \\
\hline Total & & $\mathbf{2 1 5}$ & $\mathbf{1 0 0}$ \\
\hline
\end{tabular}

Source: Field Survey, 2018

\section{Learners' Demographic Characteristics}

Table 1 shows that sixty-eight (56.7\%) of respondents with low academic performance were males. The average age group was 9 to 11 years. One hundred and fourteen (95\%) were biological children living with their parents and 59.1\% of the learners came from families with one to three siblings. Six learners $(5 \%)$ indicated they were the only child of their parents. The findings reveal that, contrary to other research, a learners' performance may not be influenced by the number of siblings he/she has. Louw purported that a child who is alone with parents at home may lack contact with other children and may face difficulty adjusting in school. ${ }^{35}$ In small families, children are likely to experience adequate attention and devotion from parents. They believe that parents usually give more attention, affection and greater interaction to their first (only) and last child. ${ }^{36}$

Table 1 also indicates that sixty-eight (56.7\%) of respondents' guardians/parents representing majority of the parents were self-employed. Most of the self-employed parents were petty traders and food vendors. Those into these jobs are mainly less educated or low-income earners and so may not be supportive to their children's academic issues. ${ }^{37}$

\section{Teachers' perception on causes of low academic performance}

When asked, "What are the causes of low academic performance?", teacher respondents identified several factors which were grouped into school environment, learners' characteristics and home environment. School environmental factors include inexperienced teachers, inadequate resources, large class sizes, absenteeism of both teachers and learners and ineffective supervision of teachers among others. Regarding the home, respondents stated that parental support and involvement in learners' education, broken homes, large family sizes and socio-economic status do play a role in academic performance. Narrowing down on learners' characteristics, twenty-eight representing $80 \%$ teacher respondents were of the view that personality, temperament and self-concept to a large extent influence their academic

\footnotetext{
Daniel Andreas Louw. Human development. Pearson South Africa, 1998.

Ibid.

37 G, R. Memon, F.J. Muhammad and A. Muhammad. 'Impart of parents' socio-economic status on students' educational achievement at secondary schools of district Malir Karachi, Pakistan. Middle East Journal of Science Research, 6(6), pp 678-687
} 
performance whereas seven $(20 \%)$ respondents revealed that low academic performance is the result of poor foundation and lack of interest in learning.

Learners' perspectives on causes of low academic performance in KNUST Primary School

Table 2 shows the result of learner respondents' views on their characteristics and academic performance.

Table 2. Learners' characteristics affecting their performance Statements

\section{Responses}

\begin{tabular}{lllll} 
& $\mathbf{S A}(\%)$ & $\mathbf{A}(\%)$ & $\mathbf{D}(\%)$ & SD(\%) \\
\hline $\begin{array}{l}\text { I usually get to school on time } \\
\begin{array}{l}\text { I try to learn even when nobody has } \\
\text { ordered me to so }\end{array}\end{array}$ & $46(48.3)$ & $55(45.8)$ & $16(13.3)$ & $3(2.5)$ \\
$\begin{array}{l}\text { I enjoy being alone } \\
\begin{array}{l}\text { My peers always make me feel } \\
\text { Rejected }\end{array}\end{array}$ & $11(9.1)$ & $17(14.2)$ & $62(51.7)$ & $30(25)$ \\
$\begin{array}{l}\text { I usually feel the love and warmth of my } \\
\text { parents }\end{array}$ & $72(60.0)$ & $35(29.2)$ & $8(6.7)$ & $5(4.2)$ \\
$\begin{array}{l}\text { I continually play in class during teaching } \\
\text { and learning }\end{array}$ & $6(5.0)$ & $40(33.3)$ & $46(38.3)$ & $28(23.3)$ \\
$\begin{array}{l}\text { I am interested in sporting activities } \\
\text { Absenteeism has no effect on learning }\end{array}$ & $37(30.8)$ & $35(29.2)$ & $31(25.8)$ & $17(14.2)$ \\
\hline
\end{tabular}

Source: Field Survey, 2018

SA-Strongly agree, A-Agree, D- Disagree and SD-Strongly disagree

\section{School attendance and absenteeism}

Table 2 shows that one hundred and one (84.2\%) respondents agreed that they arrive at school on time while nineteen of them representing $15.8 \%$ disagreed. Lateness may be due to varying reasons but if it becomes persistent, the child is likely to miss subjects taught during the first and second periods. During the interviews, parent respondents revealed that children's lateness to school is partly attributed to distance and heavy vehicular traffic.

It was disclosed that children feel uncomfortable when they are punished for lateness and sometimes even when no punishment is meted out the child feels uneasy. It also reduces a child's confidence level as other children tease perpetual latecomers. Lateness affects a learner's eligibility for certain positions in the school. Teachers should take up the responsibility of encouraging parents to assist their children in the early mornings at home to enable them get to school on time. Eighty-seven representing $72.5 \%$ learner respondents disagreed that absenteeism has no effect on learning. Only thirty-three representing $27.5 \%$ agreed. Etsey found that regular school attendance influences learning. ${ }^{38}$ Teacher respondents reported that few learners absent themselves as registered in class record books. Generally, absenteeism is recorded low in KNUST Primary School. On the average, learners were absent once or twice in a term. There are various reasons for absenteeism but lateness, truancy and leaving school without permission greatly affect academic success. ${ }^{39}$ Therefore, learners are to be encouraged to be regular and punctual to school.

\section{Motivation}

As indicated in Table 2, sixty-six (55\%) of learner respondents agreed that their learning is based on self-motivation whilst the remaining $45 \%$ disagreed. Considering that just a slight majority of learner respondents admitted to selfmotivation, the number that disagreed are a very significant minority. Fifty-four representing $90 \%$ of parent respondents confirmed that they usually instruct their children to learn before they do so. This extrinsic motivation can be given by both parents and teachers through rewards or positive reinforcements.

Research has revealed that psychologists have developed a plan including rewards, praise, positive self- concept

\footnotetext{
38 Kafui Etsey, "Causes of low academic performance of primary school pupils in the Shama Sub-Metro of Shama Ahanta East Metropolitan Assembly (SAEMA) in Ghana." In Proceedings of the Regional Conference on Education in West Africa. 2005.

39 Olivia Akrofi. Parental involvement of School Guidance and Counselling of the Adolescent. Unpublished. University of Cape Coast, Cape Coast, Ghana. 2009.
} 
esteem and appropriate feedback to aid teachers motivate learners in the classroom. ${ }^{40}$

Parents can also use the same plan to help children develop the habit of learning. Hussain's (2006) findings revealed that proper guidance from teachers and parents can help children to improve their academic performance. ${ }^{41}$ Aremu found that authoritative parenting more often than not results in the instillation of socially acceptable behaviour in children. Such children are able to perform better in school. ${ }^{42}$

\section{Self-concept}

From Table 2, ninety-two representing $76.7 \%$ of learner respondents, disagreed that they enjoy being alone while a significant twenty-eight representing $23.3 \%$ agreed. According to Louw et al children relate with their peers for alliance, love and companionship. ${ }^{43}$ This relationship plays a significant role in the child's social development. The most significant people in the lives of children are initially their parents; they have the greatest influence on the positive formation of a child's self-concept ${ }^{44}$. A person's self-concept is acquired through interacting with others. Parents ought to ensure that their children are not ridiculed by their peers. Low and negative self-esteem results in high rate of anxiety, poor academic performance and inadequate social adjustment. ${ }^{45}$ Majority $(80 \%)$ of parent respondents agreed that their children feel comfortable when interacting with them and peers.

Findings from teacher respondents revealed that peer teaching helps to improve the standard of low performing learners. Literature has revealed that children who are emotionally secured, have acquired preschool social experience, gained some independence, are able to control aggressive impulses and adapt better in school environment than those who face uncertainties and had little social experience outside the home. ${ }^{46}$ Sixty-six representing $55 \%$ respondents disagreed that their friends make them feel rejected. Fifty-four representing $45 \%$ agreed. The school counselor's services and skills can be of great help.

Also, teacher respondents revealed that one way of helping slow learners is to engage them in activities that enable them interact with one another and to unravel their hidden talents. Drama, singing/dancing and sports to a large extent are opportunities for learners to get to know and understand one another. Teachers need to lay emphasis on interpersonal relationship to facilitate learning ${ }^{47}$ Diaz as cited in Adane is of the view that learners' self-image and their rejection and acceptance by peers are of great worth to their academic performance. ${ }^{48}$ One hundred and seven indicating $89.2 \%$ of learner respondents agreed that they feel the warmth and love of their parents whereas thirteen, representing $10.8 \%$ disagreed. Parents who show love, warmth and compassion as well as sympathetic involvement in the lives of their children can reinforce those children's positive evaluation of themselves ${ }^{49}$ In families where children are many, parents are likely to fail in giving adequate attention and support to each child. All the parents who live with their children stated that they avail themselves and show love to their children. Children living with other people rather than their biological parents were likely to be experiencing less attention which might be perceived absence of love.

\section{Attitudes and habits}

According to Table 2, forty-six (38.3\%) learner respondents agreed that they usually played in the classroom during teaching and learning whereas the remaining $61.7 \%$ disagreed. Psychologists have come to know that some children have temperaments that make them difficult to raise, no matter the socio-economic status of parents. ${ }^{50}$ According to teacher respondents, some learners show temperamental tantrum in the classroom. Teachers and parents ought to identify learners of that nature to guide them appropriately. Here, the assistance of a professional counsellor would be of great benefit to all stakeholders, particularly the learner. This goes to emphasize the need for guidance and counselling

\footnotetext{
40 Suzanne Hidi. "Revisiting the role of rewards in motivation and learning: Implications of neuroscientific research." Educational Psychology Review 28, no. 1 (2016): 61-93. Carol S. Dweck, Gregory M. Walton, and Geoffrey L. Cohen. «Academic Tenacity: Mindsets and Skills that Promote Long-Term Learning.» Bill \& Melinda Gates Foundation (2014).

${ }^{41} \mathrm{Ch}$, Abid Hussain. "Effect of guidance services on study attitudes, study habits and academic achievement of secondary school students." Bulletin of Education \& Research 28, no. 1 (2006): 35-45.

$42 \mathrm{~S}$ Aremu and B. Oluwole. "The development and validation and academic performance. 5 Factor Inventory: An unpublished manuscript department of guidance and counselling." University of Ibadan, Ibadan (2000).

43 Daniel Andreas Louw. Human development. Pearson South Africa, 1998.

44 K. O Ajayi, A. O. Lawani, and M. O. Salomi. "The influences of self-concept and academic motivation on students' attitude to mathematics in selected secondary schools in Ogun State, Nigeria.” European Journal of Scientific Research 67, no. 3 (2012): 444-455.

45 Daniel Andreas Louw. Human development. Pearson South Africa, 1998.

46 Ibid.

47 Linda Ofosua Adane, "Factors affecting low academic achievement of pupils in Kemp Methodist Junior High School in Aburi, Eastern region." PhD diss., University of Ghana, 2013.

48 Antonia Diaz, "Personal, family, and academic factors affecting low achievement in secondary school." Electronic Journal of Research in Educational Psychology and Psychopedagogy 1, no. 1 (2003): 43-66.

49 Chané Kotzé. "The child's psychological experience of the parent's new partner divorce.” PhD diss., 2008.

50 Daniel Andreas Louw. Human development. Pearson South Africa, 1998.
} 
services in the basic school

Typically, children with Attention Deficiency Hyperactive Disorder (ADHD) and Attention Deficit Disorder (ADD) pay less attention in the classroom. ${ }^{51}$ These disorders are characterized by socially disruptive behaviours; such as, attentional problems or hyperactivity. Daley et al. are of the view that children with ADHD are likely to show significant academic underachievement. Fourteen (40\%) teacher respondents confirmed that some learners are inattentive and attention seekers. They tend to disrupt the attention of studious learners during teaching and learning. Research has confirmed that learners do encounter challenges in developing positive study habits. Positive study habit is when a learner attends to school work and participates in teaching and learning processes..$^{52} \mathrm{~A}$ learner needs to put effort in learning to improve his/her academic performance.

Table 2 also shows that, seventy-two representing $60 \%$ of learner respondents agreed that they were more interested in sporting activities in school whiles forty-eight (40\%) disagreed. Children learn through play, so in the primary school they tend to be more interested in Physical Education (P. E.) and other recreational activities such as Drama Troupes, Debate Clubs etc. These activities are good for mental health. From teacher respondents, learners of low performance prefer outdoor activities in order to avoid academic exercises they consider too stressful. Parent respondents confirmed that their children prefer to play rather than studying their books.

\section{CONCLUSION}

Learner-related factors, as revealed by this study, are of great significance in academic performance. Majority of teachers attributed the learners' temperament and self-concept to their attitude to learning and therefore low academic performance. Inattentiveness and attention seeking tantrums were also identified as problematic learner-characteristics that affect their performance. Some learners expressed difficulty understanding lessons and though majority of learners claimed to be self-motivated, a significant minority required external motivation.

It is therefore recommended that, guidance and counselling units should be established in schools to render services needed to resolve learners' personal and academic challenges. Also, parents should be encouraged to discuss their children's diverse challenges with professional counsellors for assistance.

\section{BIBLIOGRAPHY}

Adane, Linda Ofosua. "Factors affecting low academic achievement of pupils in Kemp Methodist Junior High School in Aburi, Eastern region." PhD diss., University of Ghana, 2013.

Ajayi, K. O., A. O. Lawani, and M. O. Salomi. "The influences of self-concept and academic motivation on students' attitude to mathematics in selected secondary schools in Ogun State, Nigeria." European Journal of Scientific Research 67, no. 3 (2012): 444-455.

Akrofi, Olivia. Parental involvement of School Guidance and Counselling of the Adolescent.Unpublished. University of Cape Coast, Cape Coast, Ghana. 2009.

Aremu, S., and B. Oluwole. "The development and validation and academic performance. 5 Factor Inventory: An unpublished manuscript department of guidance and counselling." University of Ibadan, Ibadan (2000).

Barry, J. "The effect of socio-economic status on academic achievement [PhD dissertation]." Wichita, Kansas: Wichita State University (2005).

Carbonaro, William. “Tracking, students' effort, and academic achievement.” Sociology of Education 78, no. 1 (2005): 27-49.

Ch, Abid Hussain. "Effect of guidance services on study attitudes, study habits and academic achievement of secondary school students." Bulletin of Education \& Research 28, no. 1

Chowa, Gina. "How Do Student and School Characteristics Influence Youth Academic Performance in Ghana? A Hierarchical Linear Modeling of Baseline Data From the YouthSave Ghana Experiment." (2013).

Crosnoe, Robert, Monica Kirkpatrick Johnson, and Glen H. Elder Jr. "School size and the interpersonal side of education: An examination of race/ethnicity and organizational context." Social Science Quarterly 85, no. 5 (2004): 1259-1274.

Daley, David, and James Birchwood. "ADHD and academic performance: why does ADHD impact on academic performance and what can be done to support ADHD children in the classroom?" Child: care, health and development 36, no. 4 (2010): 455-464.

\footnotetext{
51 David Daley and James Birchwood. "ADHD and academic performance: why does ADHD impact on academic performance and what can be done to support ADHD children in the classroom?" Child: care, health and development 36, no. 4 (2010): 455-464.

52 Ibid.
} 
Dawson-Brew, Emma, Vera Ankomah-Sey, and Eric Nyarko-Sampson. "The relative effect of Field Dependent and Field Independent learning styles on the academic performance of undergraduate students of the University of Cape Coast, Ghana." IFE PsychologIA: An International Journal 18, no. 2 (2010): 48-64.

Diaz, Antonia Lozano. "Personal, family, and academic factors affecting low achievement in secondary school." Electronic Journal of Research in Educational Psychology and Psychopedagogy 1, no. 1 (2003): 4366.

Dweck, Carol S., Gregory M. Walton, and Geoffrey L. Cohen. "Academic Tenacity: Mindsets and Skills that Promote Long-Term Learning." Bill \& Melinda Gates Foundation (2014).

Erling, S. "Allocating time within the school year calendar: A review of the literature." (2007).

Etsey, Kafui. "Causes of low academic performance of primary school pupils in the Shama Sub-Metro of Shama Ahanta East Metropolitan Assembly (SAEMA) in Ghana." In Proceedings of the Regional Conference on Education in West Africa. 2005.

Ferla, Johan, Martin Valcke, and Yonghong Cai. "Academic self-efficacy and academic self-concept: Reconsidering structural relationships." Learning and individual differences 19, no. 4 (2009): 499-505.

Girmus, Ronald L. "How to Motivate Your Students." Online Submission (2012).

Hidi, Suzanne. "Revisiting the role of rewards in motivation and learning: Implications of neuroscientific research." Educational Psychology Review 28, no. 1 (2016): 61-93.

Kotzé, Chané. "The child's psychological experience of the parent's new partner divorce.” PhD diss., 2008.

Louw, Daniel Andreas. Human development. Pearson South Africa, 1998.

Memon, G.R., Muhammad, F.J. Muhammad, A. (2010). 'Impact of parents' socioeconomic status on students on students' educational achievement at secondary schools of district Malir Karachi, Pakistan.', Middle East Journal of Science Research, (2010).

Mendezabal, Marie Jean N. "Study habits and attitudes: The road to academic success." Open Science Repository Education open-access (2013): e70081928.

Michael, Ige Olusegun, and Ogunleye Akinyemi Wumi. "Causes and remedies to low academic performance of students in public secondary schools: A study of Ijero local government area of Ekiti State." (2016).

Mphale, Luke Moloko, and Mavis B. Mhlauli. "An investigation on students' academic performance for junior secondary schools in Botswana." European Journal of Educational Research 3, no. 3 (2014): 111-127.

Mutsotso, S. N., and E. S. B. Abenga. "Study methods for improving quality learning and performance in higher education." (2010).

Stewart, Endya B. "School structural characteristics, student effort, peer associations, and parental involvement: The influence of school-and individual-level factors on academic achievement." Education and urban society 40, no. 2 (2008): 179-204.

Tias, P.A, S. Istamar and Adi Atmoko. "The contribution of intelligent quotient on Biology academic achievement of senior high school students in Medan, Indonesia. (2015)

Tella, Adedeji. "The impact of motivation on student's academic achievement and learning outcomes in mathematics among secondary school students in Nigeria." Eurasia Journal of Mathematics, Science \& Technology Education 3, no. 2 (2007): 149-156.

Vellymalay, Suresh Kumar N. "The impact of parent's socioeconomic status on parental involvement at home: A case study on high achievement Indian students of a Tamil School in Malaysia." International Journal of Academic Research in Business and Social Sciences 2, no. 8 (2012): 11. 